\title{
Asbuton Pracampur Antara Harapan dan Kenyataan
}

\section{Asbuton Premix Between Hope and Reality}

\author{
H. R. Anwar Yamin ${ }^{1}$, Willy Pravianto ${ }^{2}$, Hikma Dewita ${ }^{3}$ \\ ${ }^{1,2}$ Pusat Litbang Jalan dan Jembatan \\ Jl. A. H. Nasution 264 Bandung \\ ${ }^{3}$ Universitas Tama Jagakarsa \\ Jl. T.B. Simatupang, 152 Jakarta \\ Email : ayplg@yahoo.com ${ }^{1}$, Willy.Pravianto@gmail.com ${ }^{2}$ dan hikma_dewita@yahoo.com ${ }^{3}$
}

\begin{abstract}
Preblended asbuton is one of a kind bitumen modification that used in Indonesia. From the results of laboratory tests and field trials scale, obtained that paved using asphalt mixture has better technical properties than conventional asphalt mix made bu asphalt Pen 60. Therefore, in the General Specifications of Highways 2011, this type of asphalt used for dense and heavy trafficed road. Although the long-term performance of asphaltic mixtures using preblended asbuton have not been surely known, but until now there has been a lot of road sections in Indonesia have used it. The purpose of this study was to evaluate the long-term field performance of preblended asbuton asphaltic mixtures.

To achieve these objectives, filed conditions survey, testing and sampling tests have conducted on several roads that use different preblended asbuton (further named Code-O and Code-B), which has served the traffic from one to three years. In this study, the filed long-term performance of the preblended asbuton asphaltic layer viewed from the level of damage and aging asphalt development that occurs in the field. Some conclution derived from this study were that preblended asbuton Code-O or Code-B has a good rutting resistance but preblended asbuton Code-B has a better cracking resistance than Code-O. In terms of shortterm aging point of view, preblended asbuton Code-O are better than asphalt Pen 60 and contrary to the Code-B, but for long-term the aging resistance either of preblended asbuton Code-O or Code-B was relative similar to asphalt Pen 60.
\end{abstract}

Keywords : Asbuton preblended, short-long term performance, rate of deterioration, asphalt aging

\section{PENDAHULUAN}

Campuran beraspal merupakan campuran antara agregat dengan aspal yang dicampur baik secara panas, hangat ataupun dingin. Persentase pengunaan aspal dalam campuran beraspal adalah sangat kecil dibandingkan dengan persentase penggunaan agregat. Namun demikian, sifat-sifat aspal memberikan pengaruh yang tidak kalah pentingnya dibandingkan dengan pengaruh sifat-sifat agregat.

Aspal penetrasi 60 (Pen 60) adalah tipe aspal keras yang umumnya digunakan di Indonesia. Dalam Spesifikasi Umum Bina Marga (BM, 2011) disebutkan bahwa Pen 60 harus memiliki nilai penetrasi antara 60-70 dengan nilai titik lembek di atas $48^{\circ} \mathrm{C}$, dan indeks penetrasi lebih besar atau sama dengan besar $-0,5$. Dengan sifat ini, aspal Pen 60 kurang cocok digunakan sebagai bahan pengikat campuran beraspal untuk lapis permukaan terutama pada jalan-jalan yang melayanai lalu lintas berat di Indonesia.

Untuk mengatasi keterbatasan penggunaan aspal Pen 60 tersebut, digunakanlah aspal modifikasi. Pada prinsipnya, aspal modifikasi yang digunakan di Indonesia adalah aspal Pen 60 yang sifat sifatnya dimodifikasi dengan melalui penambahan suatu bahan tertentu (modifier) sehingga aspal baru yang dihasilkan dapat memberikan kinerja yang lebih baik. Banyak jenis modifier yang 
dapat digunakan untuk memodifikasi sifat aspal, salah satunya adalah asbuton.

Asbuton adalah aspal alam yang penggunaannya di Indonesia sudah tidak asing lagi. Salah satu dari teknologi asbuton yang sudah banyak digunakan adalah asbuton pracampur. Asbuton pracampur adalah salah satu dari jenis aspal modifikasi yang digunakan di Indonesia. Asbuton pracampur dibuat dengan menggunakan aspal Pen 60 atau Pen 80 dan asbuton semi ekstraksi. Aspal modifikasi yang dihasilkan dari pencampuran kedua bahan ini diyakini dapat meningkatkan kinerja campuran beraspal dan dapat mensubstitusi sebagian penggunan aspal Pen 60.

Dari hasil pengujian di laboratorium dan skala uji coba lapangan, diperoleh hasil bahwa campuran beraspal yang menggunakan asbuton pracampur memiliki sifat teknis yang lebih baik dari pada campuran beraspal konvensional (dibuat mengunakan aspal Pen 60) sehingga dalam Spesifikasi Umum Bina Marga (BM, 2011), asbuton pracampur diperuntukan penggunaannya untuk jalan yang melayani lalu lintas berat dan padat, yaitu; untuk lalu-lintas rencana $>10$ juta ESA atau LHR $>2000$ kendaraan dan jumlah kendaraan truk lebih dari $15 \%$ dan atau untuk ruasruas jalan yang memiliki temperatur perkerasan yang tinggi, lebih tinggi dari titik lembek aspal Pen 60.

Berdasarkan spesifikasi ini, telah banyak ruas-ruas jalan di Indonesia yang melayani lalu lintas berat dan padat seperti ruas Batas Padang-Painan, Sentolo-Milir, Batas Jogyakarta-Kulon Progo, By Pass Mojokerto, Manyar - Gresik, Rembang Bulu, Tulung Agung-Trenggalek, Lingkar Nagreg dan lain sebagainya telah dilapis ulang dengan menggunakan campuran beraspal dengan bahan pengikat asbuton pracampur. Dengan penggunaan asbuton pracampur ini diharapkan kinerja perkerasan pada ruas-ruas jalan tersebut menjadi lebih baik.
Tujuan dari studi ini adalah untuk mengevaluasi apakah asbuton pracampur dengan sifat-sifat yang seperti disyaratkan dalam Spesifikasi Umum Bina Marga (BM, 2011) dapat memberikan kinerja jangka panjang seperti yang diharapkan.

\section{Perkembangan Teknologi Asbuton}

Sejak diketemukan pada tahun 1924 dan mulai diproduksi sejak tahun 1926 terjadi pasang surut penggunaan asbuton sebagai bahan perkerasan jalan di Indonesia. Sejak diketemukannya, teknologi pemakaian asbuton terus berevolusi mulai dari asbuton konvensional, asbuton halus, asbuton mikro, mastik asbuton, asbuton butir, asbuton pracampur dan asbuton murni.

Perkembangan teknologi asbuton ini didorong oleh perkembangan teknologi produksi asbuton yang bertujuan untuk mendapatkan kualitas campuran beraspal yang menggunakan asbuton secara memuaskan.

Secara umum, karena asbuton ini merupakan aspal alam, variabilitas kandungan bitumen dan sifat-sifat teknisnya bervariasi antara satu deposit dengan deposit lainnya, sehingga menyebabkan kesulitan dalam perencanaan campuran maupun penggunaannya bila yang digunakan adalah asbuton konvensional, yaitu asbuton yang memiliki ukuran butir maksimum 12,7 mm yang didapat dari pemecahan langsung asbuton hasil penambangan. Percobaan yang menggunakan asbuton konvensional yang dilakukan oleh Dairi (1992) menunjukkan bahwa waktu yang butuhkan bahan peremaja (flux oil atau bunker oil) agar bisa masuk ke dalam butiran asbuton adalah 254 hari. Oleh karena itu, Purwadi et al (1998) menyarankan untuk menggunakan bahan peremaja yang lebih encer lagi sehingga bahan peremaja tersebut dapat lebih mudah masuk ke dalam butiran asbuton dan dapat melunakkan bitumen asbuton serta memobilisasikanya secara 
merata di dalam campuran beraspal. Dari percobaan yang dilakukannya, dimana butir asbuton dicampur dengan kerosin dengan perbandingan $67 \%$ asbuton dan $33 \%$ kerosin, yang kemudian diaduk selama satu jam pada temperatur $90^{\circ} \mathrm{C}$, hanya $60 \%$ bitumen asbuton yang bisa keluar dari butiran tersebut. Hal ini membuktikan bahwa memobilisir bitumen dari butiran asbuton adalah suatu hal yang sangat sulit dan homogenitas campuran yang dihasilkan juga sulit untuk dicapai.

Perkembangan selanjutnya asbuton konvensional ini adalah dengan menyeragamkan produk asbuton yang dihasilkan, sehingga dikenal istilah asbuton B16, B18 dan B20 dimana angka 16, 18 dan 20 menunjukkan presentase kadar bitumen yang dikandung asbuton tersebut. Dengan demikian diharapkan ketepatan perencanaan campuran beraspal akan menjadi lebih baik lagi. Disamping jenis asbuton konvensional muncul pula pabrikpabrik yang memproduksi asbuton halus, asbuton mikro dan mastik asbuton. Dengan adanya pabrik-pabrik ini, selain keseragaman kandungan bitumennya, produk yang telah banyak beredar saat inipun tidak lagi berukuran maksimum $12,7 \mathrm{~mm}$ tetapi sudah lebih halus lagi menjadi ukuran maksimum 2,36 $\mathrm{mm}$ dan dikemas dengan kemasan plastis yang kedap air. Sehingga dengan demikian diharapkan homogenitas dan kualitas campuran yang menggunakan asbuton dapat lebih terjamin.

Selain tetap memperkecil ukuran butir asbuton dan tetap menjaga kadar kandungan bitumennya, perkembangan selanjutnya untuk asbuton butir adalah menyeragamkan kekerasan bitumen dari asbuton tersebut, sehingga dikenal istilah asbuton Butir (B) 5/20, 15/20, 15/25 dan $20 / 25$, Walaupun teknologi asbuton yang terakhir ini sudah cukup berhasil untuk mengatasi kelemahan asbuton sebagai bahan pengikat dalam campuran beraspal, tetapi persentase substitusi terhadap aspal minyak masih sangat sedikit, yaitu maksimum hanya 3\% saja. Belakangan muncul asbuton B 50/30 yang dapat mensubstitusi aspal minyak sampai $75 \%$ dalam campuran beraspal.

Dengan muncul dan maraknya penggunaan aspal yang dimodifikasi, dengan penambahan additive seperti polimer, yang tahan terhadap temperatur tinggi dan beban berat, pada tahun 2000-an Puslitbang Jalan dan Jembatan bekerja sama dengan produsen asbuton telah mengkaji pembuatan aspal yang dimodifikasi dengan asbuton, biasa disebut asbuton pracampur.

Berdasarkan keinginan untuk mengoptimalkan penggunaan asbuton, baik dari segi fungsinya dalam suatu campuran beraspal maupun dalam jumlah penggunaannya maka saat ini telah diperkenalkan jenis produk asbuton yang dihasilkan dengan cara semi ataupun full ekstraksi. Kalau untuk menghasilkan asbuton sebelumnya digunakan asbuton dari deposit Kabungka maka untuk menghasilkan asbuton hasil ekstraksi ini digunakan asbuton dari deposit Lawele yang mempunyai sifat aspal yang lebih lunak dibandingkan dengan asbuton dari deposit Kabungka. Dari studinya, Affandi (2006) menyimpulkan bahwa fungsi dan penggunaan bitumen asbuton hasil proses ekstraksi pada campuran beraspal menunjukkan efektifitas yang maksimal yang ditandai dengan persentase penggunaannya dapat mencapai $100 \%$ dari kadar aspal yang dibutuhkan dalam campuran beraspal. Kesimpulan lain yang didapatkannya adalah bahwa bitumen asbuton hasil ekstraksi akan meningkatkan kinerja perkarasan jalan di daerah yang beriklim panas termasuk Indonesia.

Berdasarkan Peraturan Menteri Pekerjaan Umum Nomor 35/PRT//M.2006 tentang Peningkatan Pemanfaatan Aspal Buton untuk Pemeliharaan dan Pembangunan Jalan, jenis-jenis produk asbuton yang direkomendasikan 
penggunaannya sebagai bahan perkerasan jalan adalah asbuton butir, pracampur dan asbuton murni hasil ekstraksi.

Namun sampai saat ini jenis produk asbuton yang digunakan baru sampai sebatas asbuton butir, pracampur. Asbuton murni belum dapat di produksi secara missal, masih sebatas percobaan di laboratoirum.

\section{Asbuton Pracampur atau Semi Ekstraksi}

Asbuton pracampur (preblended) adalah jenis teknologi asbuton yang saat ini dianggap paling menjanjikan untuk digunakan sebagai bahan pengikat pada campuran beraspal. Asbuton pracampur merupakan campuran antara asbuton butir yang telah di ekstraksi sebagian (semi ekstraksi) sehingga kadar bitumen naik menjadi $40 \%$ - 60\%. Kemudian bitumen asbuton ini dicampur dengan aspal minyak Pen 60 atau pen 80 dengan komposisi tertentu pada temperatur $155^{\circ} \mathrm{C}$ sehingga dihasilkan aspal modifikasi dengan sifatsifat yang memenuhi sifat yang diinginkan. Menurut Spesifikasi Umum Bina Marga 2011 (BM, 2011), persyaratan aspal keras yang dimodifikasi dengan asbuton adalah seperti yang ditunjukkan pada Tabel 1 .

Dengan sifat-sifat tersebut, saat ini asbuton pracampur sudah banyak diproduksi dan digunakan sebagai bahan pengikat campuran beraspal untuk jalanjalan yang melayani lalu lintas berat dan padat di Indonesia.

Dalam penggunaannya, asbuton pracampur dapat digunakan secara langsung untuk pembuatan campuran beraspal panas dengan cara yang sama seperti bila menggunakan aspal Pen 60 . Namun demikian, persentase kandungan mineral dalam asbuton ini harus dipertimbangkan sebagai bagian dari bahan pengisi dalam campuran.

\section{Pengaruh Lingkungan terhadap Kinerja Lapis Beraspal}

Kerusakan yang terjadi pada lapis permukaan jalan beraspal dapat disebabkan oleh kombinasi faktor-faktor seperti lalu lintas, lingkungan, rencana awal dan kwalitas pekerjaan. Dari keempat faktor ini, lalu lintas, lingkungan dan interaksi antara keduanya merupakan penyebab utama kerusakan pada lapis permukaan beraspal tersebut (Turki et al. 1993). Sebagai contoh, kerusakan berupa alur (rutting) dan retak buaya adalah jenis kerusakan yang disebabkan oleh lalu lintas. Sedangkan jenis kerusakan yang disebabkan oleh lingkungan atau yang bukan disebabkan oleh pengaruh lalu lintas adalah retak melintang dan retak memanjang pada permukaan lapis beraspal.

\section{Oksidasi Pada Campuran Beraspal}

Hasil penelitian yang dilakukan oleh TRL di daerah tropis menunjukkan bahwa model kegagalan lapis beraspal di daerah tropis berbeda dengan model kegagalan yang biasanya terjadi di daerah sub-tropis. Perbedaan ini menunjukkan bahwa iklim sangat mempengaruhi kinerja campuran beraspal (TRL, 1993).

Akibat panas yang tinggi, pengerasan aspal akibat penuaan lebih cepat terjadi di daerah yang beriklim tropis dari pada di daerah sub-tropis. 
Tabel 1. Persyaratan Aspal Dimodifikasi Dengan Asbuton (BM, 2011)

\begin{tabular}{lcc}
\hline \multicolumn{1}{c}{ Jenis Pengujian } & Metode & Persyaratan \\
\hline Penetrasi, 25 'C; 100 gr; 5 dctik; 0,1 mm & SNI 06-2456-1991 & $40-55$ \\
Titik Lembek, ${ }^{\circ} \mathrm{C}$ & SNI 06-2434-1991 & Min. 55 \\
Titik Nyala, ${ }^{\circ} \mathrm{C}$ & SNI 06-2433-1991 & Min. 225 \\
Daktilitas; $25^{\circ} \mathrm{C}, \mathrm{cm}$ & SNI 06-2432-1991 & Min. 50 \\
Berat jenis & SNI 06-2441-1991 & Min. 1,0 \\
Kelarutan dalam Trichlor Ethylen, \% berat & RSNI M-04-2004 & Min. 90 \\
Penurunan Berat (dengan TFOT), \% berat & SNI 06-2440-1991 & Max. 2 \\
Penetrasi setelah kehilangan berat, \% asli & SNI 06-2456-1991 & Min. 55 \\
Daktilitas setelah TFOT, cm & SNI 06-2432-1991 & Min. 50 \\
Mineral Lolos Saringan No. 100, \% & SNI 03-1968-1990 & Min. 90 \\
\hline
\end{tabular}

Pengerasan ini terutama terjadi pada permukaan beraspal yang terekspos langsung terhadap lingkungan. Oleh sebab itu keretakan pada lapis permukaan beraspal di daerah tropis akan terjadi dengan cepat sebelum retak di daerah lain terjadi. (TRL, 1993; Rolt et al. 1986).

Penuaan aspal adalah suatu parameter yang baik untuk mengetahui durabilitas campuran beraspal. Penuaan aspal ini disebabkan oleh dua faktor utama, yaitu penguapan fraksi minyak ringan yang terkandung dalam aspal dan oksidasi (penuaan jangka pendek, short-term aging), dan oksidasi yang progresif (penuaan jangka panjang, long-term aging). Penuaan pada aspal, apapun penyebabnya, akan menyebabkan terjadinya pengerasan pada aspal dan selanjutnya akan meningkatkan kekakuan campuran beraspal sehingga akan mempengaruhi kinerja campuran tersebut. Peningkatan kekakuan ini akan meningkatkan ketahanan campuran terhadap deformasi permanen dan kemampuan untuk menyebarkan beban yang diterima, tetapi dilain pihak akan menyebabkan campuran menjadi lebih getas sehingga akan cepat retak dan akan menurunkan ketahanan lelahnya (fatigue).

Dalam dua proses penuaan seperti yang telah disebutkan di atas, oksidasi merupakan suatu faktor penting yang menentukan kecepatan penuaan. Kecepatan penuaan jangka panjang semata-mata disebabkan oleh oksidasi. Kecepatan oksidasi yang terjadi sangat dipengaruhi oleh rongga udara yang terkandung dalam campuran dan lingkungan dimana campuran ini dihampar. Dari ke-dua hal tersebut, Glenn et al. (1981) mengatakan bahwa lingkungan lebih memberikan pengaruh pada penuaan aspal dibandingkan dengan rongga udara dalam campuran atau porositas agregat yang digunakan. Pendapat ini diperkuat oleh Yau et al. (1985) yang mengatakan bahwa oksidasi adalah penyebab utama pengerasan aspal yang merupakan hasil interaksi antara aspal dengan lingkungan. Corne (1986) telah membuktikan, seperti yang ditunjukkan pada Gambar 1, bahwa pada daerah tropis (diwakili oleh Indonesia), pengerasan aspal akibat oksidasi ini lebih cepat dari daerah sub-tropis (diwakili oleh Inggris). Hal ini juga telah dibuktikan juga oleh Dickinson et al. $(1958 ; 1980)$ yang menyatakan bahwa setiap kenaikan temperatur perkerasan $10^{\circ} \mathrm{C}$, kecepatan oksidasi pada campuran beraspal akan meningkat dua kalinya. 


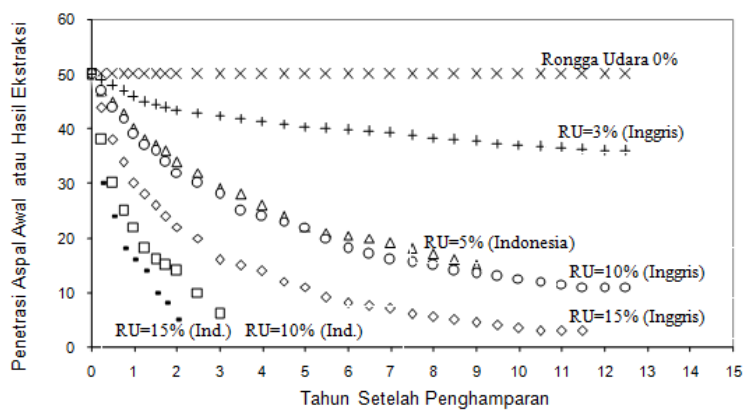

Gambar 1. Penuaan campuran beraspal di daerah tropis (Indonesia) dan subtropis (Inggris) pada berbagai kandungan rongga udara (Corne, 1986)

\section{Evaluasi Kondisi Struktural Perkerasan Jalan}

Ada beberapa metode yang dapat digunakan untuk mengestimasi kekuatan struktur perkerasan jalan. Secara umum kekuatan ini dapat dinyatakan oleh nilai modulus perkerasan ataupun Structural Number-nya (SN). Nilai SN digunakan sebagai parameter perencanaan tebal lapisan perkerasan dan sebagai indikator kekuatan (AASHTO, 1993). Indikator kekuatan struktural suatu perkerasan dapat dilihat dari rasio antara nilai struktural perkerasan yang ada $\left(\mathrm{SN}_{\mathrm{ef}}\right)$ terhadap nilai struktural yang diperlukan oleh perkerasan (SN) tersebut untuk suatu masa pelayanan tertentu. Rasio ini dinyatakan sebagai Structural Conditon Index (SCI) sebagaimana ditunjukan pada Persamaan 1. Perkerasan yang memiliki SCI sama dengan atau lebih besar dari satu $(\mathrm{SCI} \geq 1)$ berarti perkerasan tersebut secara struktur masih kuat untuk melayani lalu lintas rencana. Perbaikan struktural untuk menaikan daya dukung harus dilakukan apabila perkerasan tersebut memiliki SCI kurang dari 1.

Dimana :

$$
S C I=\frac{S N_{e f}}{S N}
$$

$\mathrm{SN}_{\mathrm{ef}}=$ Nilai struktural perkerasan yang ada, inch

$\mathrm{SN}=$ Nilai struktural perkerasan yang dibutuhkan, inch

$\mathrm{D}=$ Tebal total perkerasan, inch
$\mathrm{Ep}=$ Modulus pekerasan eksisting, $\mathrm{psi}$

Nilai $\mathrm{SN}_{\mathrm{ef}}$ dapat diperoleh dengan menggunakan Persamaan 2 (Zhanmin et al., 2003). Pada persamaan ini, nilai modulus perkerasan diperoleh dari hasil pengolahan data pengujian lendutan alat FWD pada perkerasan yang akan ditinjau SCI-nya.

$$
S N_{\text {eff }}=0,0045 * D * E_{p}^{0,333}
$$

\section{Hipotesis}

Campuran bersapal yang dibuat dengan menggunakan asbuton pracampur memberikan kinerja jangka panjang yang lebih baik dari campuran beraspal konvensional yang dibuat dengan menggunakan aspal Pen 60.

\section{METODOLOGI}

Campuran beraspal seyogyanya memiliki kinerja jangka pendek dan jangka panjang yang baik. Kedua kinerja tersebut dapat diuji dan disimulasikan di laboratorium. Namun demikian, pengamatan langsung di lapangan adalah cara yang paling baik untuk mengetahui kinerja jangka panjangnya. Untuk itu, metode yang digunakan dalam studi ini adalah dengan pengamatan dan pengujian langsung di lapangan dan pengujian di laboratorium pada contoh uji yang diambil di lapangan pada lapis beraspal yang telah memiliki umur pelayanan tertentu.

Dalam studi ini, kinerja jangka panjang campuran beraspal dilihat dari jenis dan kuantitas kerusakan yang terjadi serta kecepatan penuan aspal akibat proses oksidasi di lapangan yang diwakili oleh penurunan nilai penetrasi aspal.

\section{HASIL}

Survey kondisi perkerasan jalan dan pengambilan contoh uji di lapangan dilakukan antara bulan Juni - September 2012. Ruas jalan yang disurvey adalah ruas jalan dengan lapis permukaan beraspal yang dibuat dengan asbuton pracampur (dalam studi ini diberi Kode-O dan Kode- 
B) yang telah memiliki umur pelayanan antara $1-3$ tahun. Ruas tersebut antara lain adalah Batas Batas Padang-Painan, Sentolo-Milir, Batas Jogyakarta-Kulon Progo, By Pass Mojokerto, Manyar Gresik, Rembang - Bulu, Tulung AgungTrenggalek dan Lingkar Nagreg. Jenis dan kuantitas kerusakan yang terjadi serta indikator kekuatan stuktrur ruas-ruas yang diuji adalah seperti yang diberikan pada Tabel 2. Total nilai kerusakan dan nilai penurunan penetrasi aspal dari contoh uji ditunjukan pada Gambar 2 dan Gambar 3.

Tabel 2. Jenis dan kuantitas kerusakan lapis beraspal dengan asbuton pracampur Persentase Luas Kerusakan

\begin{tabular}{|c|c|c|c|c|c|c|c|}
\hline Umur & SCI & $\begin{array}{l}\text { Alur } \\
\text { (a) }\end{array}$ & $\begin{array}{l}\text { Retak } \\
\text { (b) }\end{array}$ & $\begin{array}{c}\text { Tambalan } \\
\text { (c) }\end{array}$ & $\begin{array}{l}\text { Lubang } \\
\text { (d) }\end{array}$ & $\begin{array}{l}\text { 'elepasar } \\
\text { (e) }\end{array}$ & $\begin{array}{l}n \quad \text { Total } \\
(b+c+d+e)\end{array}$ \\
\hline & \multicolumn{7}{|c|}{ Asbuton Pracampur Kode-O } \\
\hline 3 & 1,04 & 0.34 & 20.04 & 12.27 & 0.00 & 0.00 & 32.31 \\
\hline 2 & 1,16 & 0.08 & 4.10 & 0.14 & 0.01 & 0.07 & 4.32 \\
\hline 1 & 1,44 & 0.00 & 0.63 & 0.11 & 0.00 & 0.00 & 0.74 \\
\hline \multirow[t]{2}{*}{0} & - & 0.00 & 0.00 & 0.00 & 0.00 & 0.00 & 0.00 \\
\hline & \multicolumn{7}{|c|}{ Asbuton Pracampur Kode-B } \\
\hline 3 & 1,11 & 0.00 & 0.87 & 0.00 & 0.00 & 0.00 & 0.87 \\
\hline 2 & 1,11 & 0.00 & 0.63 & 0.00 & 0.10 & 0.00 & 0.73 \\
\hline 1 & 1,12 & 0.01 & 0.21 & 0.00 & 0.0 & 0.00 & 0.21 \\
\hline 0 & 1,18 & 0.00 & 0.00 & 0.00 & 0.00 & 0.00 & 0.00 \\
\hline
\end{tabular}

\section{PEMBAHASAN}

Dari Tabel 2 dapat dilihat bahwa untuk asbuton pracampur Kode-O, kerusakan jenis alur, retak, tambalan, lubang dan pelepasan butir (raveling) sudah mulai terjadi mulai dari tahun pertama lapisan tersebut melayani lalu lintas. Sedangkan untuk asbuton pracampur Kode-B, sampai dengan umur pelayanan tiga tahun, tambalan dan pelepasan butir belum terjadi.

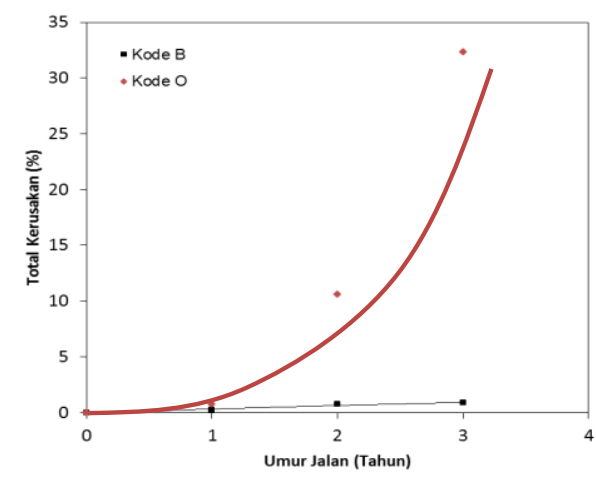

Gambar 2. Perkembangan tingkat kerusakan asbuton pracampur

Retak adalah jenis kerusakan dominan yang terjadi baik pada lapisan asbuton pracampur Kode-O maupun Kode-B. Namun demikian, seperti yang ditunjukan pada Gambar 2, besarnya tingkat kerusakan yang terjadi jauh berbeda. Pada 
gambar ini dapat dilihat bahwa perkembangan kerusakan asbuton pracampur Kode-O lebih cepat dibandingkan dengan Kode- B. Pada umur 3 tahun, total tingkat kerusakan asbuton pracampur Kode-O adalah sebesar 32,31\%. Dengan nilai ini, berdasarkan SK Dirjen Bina Marga No. 77/KPTS/Db/1990 (BM, 1990), dapat dikatakan bahwa asbuton pracampur Kode-O pada umur 3 tahun sudah mengalami kerusakan berat. Sedangkan untuk asbuton pracampur Kode-B, dengan total tingkat total kerusakan umur 3 tahun sebesar 0,87\% maka dapat dikatagorikan masih dalam kondisi baik.

Kerusakan yang terjadi pada ruas jalan yang disurvey diyakini bukan sebagai akibat dari lemahnya daya dukung perkerasan. Dengan nilai SCI (lihat Tabel 2) pada umur pelayanan tahun ketiganya yang masih lebih besar dari satu, menunjukkan bahwa ruas-ruas jalan tersebut masih memiliki daya dukung yang baik dan masih mampu melayani lalu lintas beberapa tahun ke depan. Berdasarkan nilai SCI ini, kerusakan yang terjadi pada lapis beraspal diduga kuat diakibatkan oleh perubahan sifat campuran beraspal itu sendiri.

Perubahan sifat campuran pada lapis beraspal yang sudah terhampar di lapangan dapat disebabkan oleh dua hal, yaitu karena terjadinya perubahan gradasi agregat dan perubahan sifat pada aspal pembentuknya. Berdasarkan jenis kerusakan dominan (retak) yang terjadi pada ruas yang menggunakan asbuton pracampur ini, perubahan sifat aspal yang diduga kuat menjadi penyebab utama dari kerusakan tersebut.

Pada Gambar 3 ditunjukan tingkat penuaan aspal yang diwakili oleh perubahan tingkat kekerasan aspal yang terjadi sebagai akibat dari proses oksidasi jangka pendek pada saat proses produksi di Asphalt Mixing Plant (AMP) dan oksidasi panjang yang terjadi secara progresif di lapangan akibat lingkungan. Dari gambar ini dapat dilihat bahwa penuaan aspal yang terjadi selama proses produksi di AMP dan penghamparan campuran dengan asbuton pracampur Kode-O lebih kecil dibandingan dengan asbuton pracampur Kode-B. Akibat proses penuaan jangka pendek di AMP dan penghamparan di lapangan, persentase nilai penetrasi asbuton Kode-O dan Kode-B masingmasing masih sekitar $85 \%$ dan $69 \%$ terhadap nilai penetrasi awalnya. Namun demikian, akibat oksidasi yang progresif di lapangan kedua aspal tersebut sama-sama dengan cepat mengalami penuaan yang tinggi dengan kecepatan yang relatif sama. Apabila nilai penetrasi aspal sebesar 20 merupakan nilai akhir dimana aspal telah dianggap mencapai kondisi kritisnya (Yeaman et al,----), maka umur pelayanan asbuton pracampur baik Kode-O maupun Kode-B dapat dikatakan tidak mencapai 2 tahun. Hal ini menunjukkan secara jelas bahwa penurunan penetrasi aspal berhubungan erat dengan besarnya tingkat kerusakan yang terjadi.

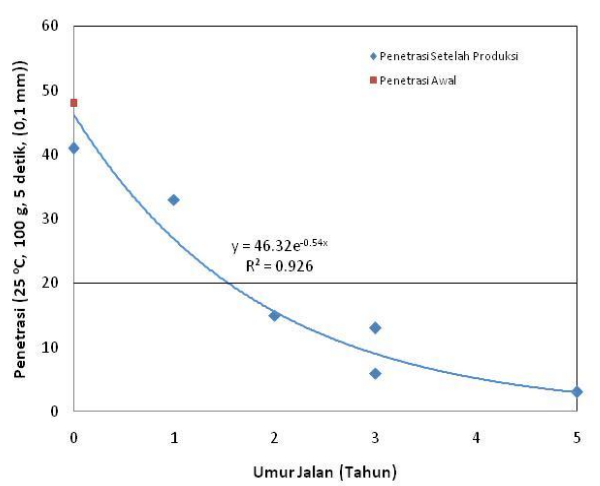

a.Asbuton pracampur Kode-O

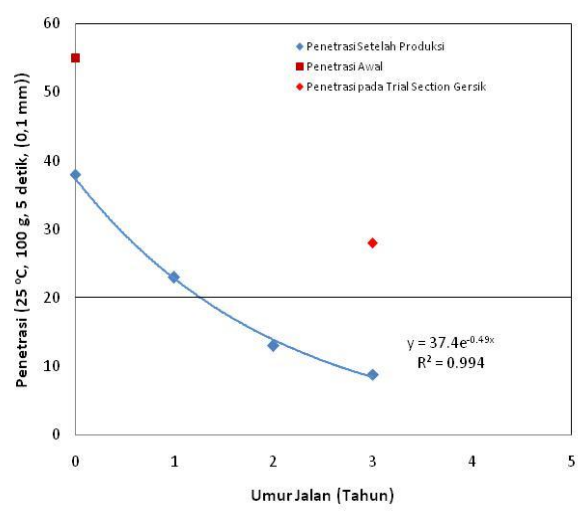

b. Asbuton pracampur Kode-B

Gambar 3. Penurunan tingkat kekerasan aspal akibat oksidasi di lapangan 
Untuk asbuton pracampur Kode-B, dari hasil pengujian penetrasi diketahui bahwa aspal ada ruas jalan yang menggunakan aspal jenis ini (ruas ManyarGersik) yang masih memiliki nilai penetrasi sebesar 28 (Gambar 3.b) walaupun ruas jalan tersebut telah melayani lalu lintas berat dan padat selama 3 tahun. Sampai dengan saat ini (umur 3 tahun), ruas jalan tersebut masih memiliki permukaan dengan kondisi yang sangat baik.

Pada Gambar 4 ditunjukan hubungan antara penurunan nilai penetrasi aspal dengan total luas kerusakan lapis beraspal yang terjadi di lapangan. Total kerusakan yang disajikan dalam gambar ini adalah persentase total jenis kerusakan yang disebabkan oleh perubahan sifat aspal, antara lain yaitu retak, tambalan, lubang dan pelepasan butir. Dari gambar terlihat jelas bahwa kenaikan persentase total kerusakan permukaan jalan memiliki hubungan yang erat dengan penurunan nilai penetrasi aspalnya. Pada Gambar 4.a dapat dilihat bahwa pada nilai penetrasi 20 , persentase total kerusakan yang terjadi pada lapis beraspal dengan bahan pengikat asbuton pracampur Kode-O adalah sebesar 4\%. Nilai total kerusakan ini terjadi pada umur perkerasan baru mencapai 1,5 tahun. Sedangkan untuk asbuton pracampur Kode-B (Gambar 4.b), nilai penetrasi 20 terjadi pada umur perkerasan 1,2 tahun dengan persentase total kerusakannya adalah $0,35 \%$. Dari ini dapat disimpulkan bahwa waktu pencapaian penetrasi 20 untuk asbuton pracampur Kode-O tidak jauh berbeda, tetapi tingkat kerusakan yang dihasilkannya cukup jauh berbeda.

Tingkat penuaan asbuton pracampur Kode-O dan Kode-B seyogyanya dapat dibandingkan dengan tingkat penuaan aspal lainnya pada campuran beraspal yang sejenis, tetapi karena ketiadaan data histori maka pada studi ini penuaannya dibandingkan dengan penuaan aspal Pen 60 pada campuran jenis SMA (Split Mastic Asphalt) dan HRS (Hot Rolled Sheet) sebagaimana ditunjukkan pada Gambar 5.
Dari gambar ini dapat dilihat kencederungan penurunan penetrasi aspal akibat proses penuaan jangka panjang asbuton pracampur Kode-O dan Kode-B relatif sama, namun nilai asbuton Kode-O memiliki nilai penetrasi sisa yang lebih tinggi dari asbuton Kode-B. Hal ini disebabkan karena kehilangan minyak ringan asbuton Kode-B akibat penuaan jangka pendeknya di AMP lebih tinggi dari asbuton Kode-O.

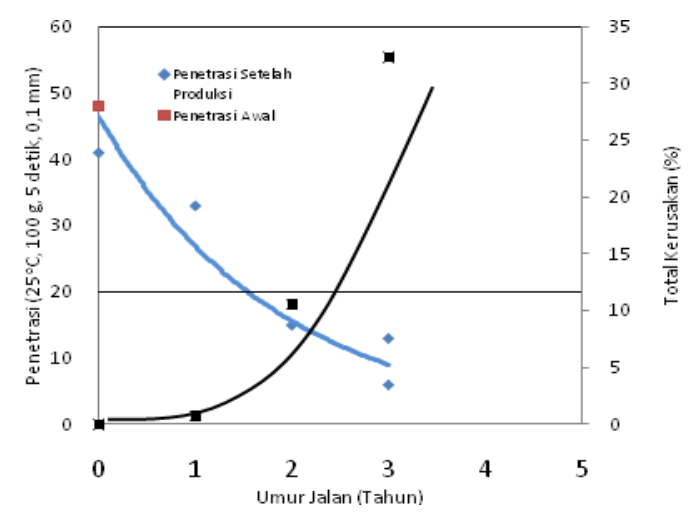

a.Asbuton pracampur Kode-O

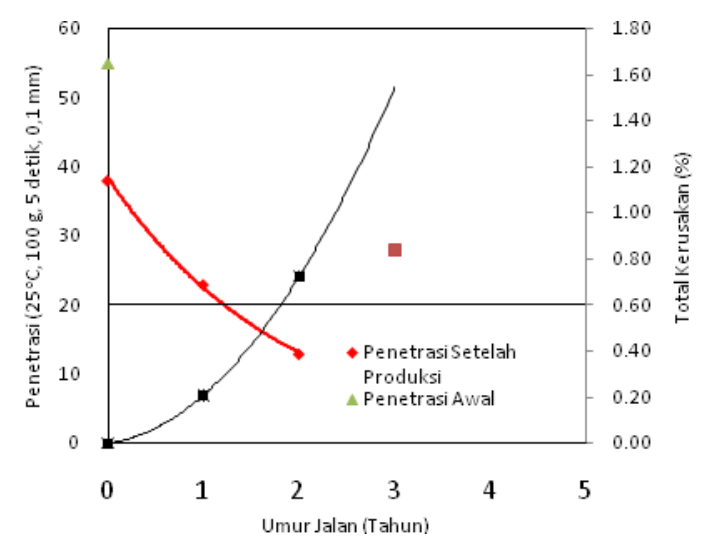

b. Asbuton pracampur Kode-B

Gambar 4. Tingkat kekerasan aspal versus kuantitas kerusakan

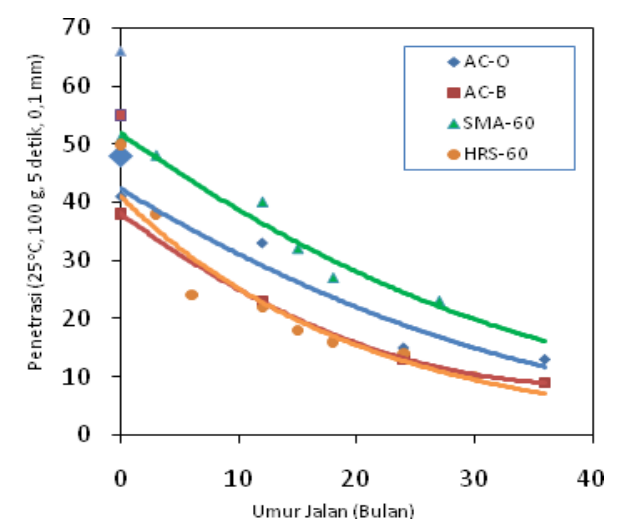


Gambar 5. Kecepatan penuaan aspal di lapangan pada beberapa jenis campuran

Bila kencederungan penurunan penetrasi aspal akibat proses penuaan jangka panjang asbuton pracampur pada campuran AC dibandingan dengan aspal Pen 60 pada campuran HRS dan SMA, seperti yang ditunjukan pada Gambar 5, maka dapat dikatakan bahwa kencederungan penuaan jangka panjang asbuton pracampur baik Kode-O maupun Kode-B adalah retatif sama dengan aspal Pen 60. Perbedaan letak garis penuaan lebih disebabkan karena adanya perbedaan tingkat kehilangan nilai penetrasi aspal setelah penuaan di AMP seperti yang ditunjukan pada Tabel 3.

Tabel 3. Penetrasi-sisa Aspal Setelah Produksi di AMP

\begin{tabular}{|l|c|c|c|}
\hline \multirow{2}{*}{ Jenis Aspal } & \multirow{2}{*}{$\begin{array}{c}\text { Jenis } \\
\text { Campuran }\end{array}$} & \multicolumn{2}{|c|}{$\begin{array}{c}\text { Penetrasi-sisa Setelah } \\
\text { Produksi }\end{array}$} \\
\cline { 3 - 4 } & AC & dmm & $(\%)$ \\
\hline Pracampur Kode-O & 41 & 85 \\
\hline Pracampur Kode- B & AC & 38 & 69 \\
\hline Pen 60 & SMA & 51 & 77 \\
\hline Pen 60 & HRS & 50 & 76 \\
\hline
\end{tabular}

Dari Tabel 3 dan Gambar 5 dapat dilihat bahwa dari segi penuaan jangka pendek asbuton pracampur Kode-O lebih baik dari aspal Pen 60 dan sebaliknya untuk pracampur Kode-B. Sedangkan segi penuaan jangka panjangnya baik asbuton pracampur Kode-O ataupun KodeB memiliki ketahanan terhadap penuaan (aging resistance) yang relative sama dengan aspal Pen 60.

\section{SIMPULAN}

Beberapa hal yang dapat disimpulkan dari studi ini antara lain adalah

- Asbuton pracampur Kode-O ataupun Kode-B memiliki ketahanan terhadap alur yang baik tetapi asbuton pracampur Kode-B memiliki ketahanan terhadap retak yang lebih baik dari Kode-O.

- Kerusakan yang dialami oleh lapis beraspal dengan asbuton pracampur Kode-O sebagai bahan pengikatnya jauh lebih besar dari asbuton pracampur Kode-B.

- Akibat penuaan jangka pendek, persentase nilai penetrasi asbuton Kode-O dan Kode-B masing-masing masih sekitar $85 \%$ dan $69 \%$ terhadap nilai penetrasi awalnya. Namun kecepatan penuaan jangka panjang kedua aspal tersebut adalah relatif sama.

- Waktu pencapaian penetrasi 20 untuk asbuton pracampur Kode-O tidak jauh berbeda asbuton pracampur Kode-B.

- Pada umur 3 tahun, asbuton pracampur Kode-O dikatagorikan sudah mengalami kerusakan berat dan asbuton pracampur Kode-B, masih dalam kondisi baik.

ari segi penuaan jangka pendek asbuton pracampur Kode-O lebih baik dari aspal Pen 60 dan sebaliknya untuk pracampur Kode-B. Sedangkan dari segi penuaan jangka panjangnya baik asbuton pracampur Kode-O ataupun Kode-B memiliki ketahanan terhadap penuaan (aging resistance) yang relatif sama dengan aspal Pen 60.

\section{SARAN}

Untuk memenuhi harapan bahwa penggunaan asbuton pracampur sebagai bahan pengikat pada campuran beraspal dapat memberikan kinerja yang lebih baik dari aspal Pen 60, maka dipandang perlu : 
- Untuk memasukan sifat elastic recovery setelah kehilangan berat dalam spesifikasi asbuton pracampur.

- Perlu ada perbaikan sifat asbuton pracampur sehingga aspal tersebut tidak saja memiliki ketahanan terhadap rutting yang baik tetapi juga ketahanan terhadap retak yang tinggi.

\section{DAFTAR PUSTAKA}

AASHTO, 1993, Guide for Design of Pavement Structures, AASHTO, Washingthon, D. C.

Affandi, F., (2006), Ekstraksi Aspal Asbuton untuk Campuran Beraspal Panas, Jurnal Jalan dan Jembatan, Vol. 23 No. 1, April 2006

BM, (2011), Spesifikasi Umum Buku III, Direktorat Jenderal Bina Marga, Kementrian Pekerjaan Umum, Jakarta, Indonesia.

BM, (1990), Pembagian Tingkat Kerusakan Jalan, SK Dirjen Bina Marga No. 77/KPTS/Db/1990, Jakarta.

Corne. C. P., (1986), High Bitumen Content philosophy, Development in Highways and Transportation Technology, Pascasarjana Workshop, Vol. 2. Bandung, Indonesia.

Dairi, G., (1992), Review Pemanfaatan Asbuton sebagai Bahan Perkerasan Jalan, (Review of Asbuton as Roads materilas) Reserach Report, Institute of Road Engineering, Bandung Indonesia.

Dickinson, E. J., J. H. Nicholas and S. Boas Traube, (1958), Physical Factors Affecting The Absorption of Oxygen by Thin Films of Bituminous Binders, Journal of Applied Chemistry, Vol. 8. pp. 673-687.

Dickinson, E. J., (1980), The Hardening of Middle East Petroleum Asphalt in Pavement Surfacings, Asphalt Paving Technology, Proceeding of the Association of Asphalt Paving Technology, Vol. 49. pp. 30-63.

Glenn, R. Kemp and Nelson, H. Predoehl, (1981), A Comparasion of Field and
Laboratory Environments on Asphalt Durability, Proceeding Association of Asphalt Paving Technologies, Vol. 50. pp. 492-537. San Diego, California.

Purwadi, A., Zamhari, K., and Akoto, B., (1998), Review of Technical / Economic of Natural Asphalt, Agency for Research and Development, Institute of Road Engineering, Bandung - Indonesia.

Rolt, J., H. R. Smith and C. R. Jones, (1986), The Design and Performance of Bituminous Overlays in Tropical Environments, Proc. $2^{\text {nd }}$. Int. Conf. On The Bearing Capacity of Roads and Airfields, Plymouth, U. K.

TRL, (1993), A Guide To The Structural Design of Bituminous-Surfaced Roads in Tropical and Sub-tropical Countries, Transport Research Laboratory, Road Note 31, Crow Thorne, London, U. K.

Turki, I., Al-Suleiman, Adnan, A, Basma and Khaled Ksaibati, (1993), Examination of pure environmental effects on pavement condition,TRR. No.1388, Transportation Research Board, National Research Council, Washington D. C.

Yaw, A. Tuffour, Ilan Ishai and Joseph Craus, (1985), Relating Asphalt Aging and Durability to Its Compositional Change , Proceeding of the Association of Asphalt Paving Technology, APT, Vol. 54. pp. 163181.

Yeaman, J. and Lee, I. K., (,----), Pavement Management Handbook, Vol II. Pavement Maintenance and Rehabilitation Strategies, S.A.M.I. UNIRESEARCH

Zhanmin. Z., German. C., Lance., $M$ and Ivan., D., 2003, Evaluation of The Pavement Structural Condition at Network Level Using FWD Data, 82th Annual Meeting of The Transport Research Board., Publc in TRR Series, Washingthon, D. C. 